\title{
Sorghum forage in precision-fed dairy heifer diets
}

\author{
F. Pino and A. J. Heinrichs ${ }^{1}$ \\ Department of Animal Science, The Pennsylvania State University, University Park 16802
}

\begin{abstract}
Sorghum forage is an alternative crop that is more adapted to drier conditions and more resistant than corn to drought conditions. Thus, sorghum forage maximizes water utilization. The objective of this study was to evaluate sorghum silage (SS), including digestibility and fermentation parameters, in precision-fed dairy heifers. Eight Holstein heifers $(13.7 \pm 0.6$ mo of age and $364.8 \pm 17.64 \mathrm{~kg}$ of body weight) fitted with rumen cannulas were used in a replicated $4 \times 4$ Latin Square design; treatments were 4 levels of forage to concentrate ratios $(85: 15,75: 25,65: 35$, and 55:45). Rumen contents were sampled at various times to determine $\mathrm{pH}$ and volatile fatty acid concentrations. Dry matter (DM) and neutral detergent fiber (NDF) in situ degradation kinetics were compared between SS and corn silage (CS) diets. Fecal total collection was used to estimate apparent total-tract digestibility. Fecal grab samples at $0,6,12$, and $18 \mathrm{~h}$ after feeding were used to estimate total-tract starch digestibility. Amount of concentrate in the diet affected the time that heifers spent eating as well as rumen $\mathrm{pH}$. When the concentrate proportion of the diet increased, eating time and rumen $\mathrm{pH}$ decreased linearly. Total volatile fatty acid concentrations were not affected by treatment, but butyrate increased as the proportion of concentrate increased in the diet. Digestibility of DM and starch were higher in diets with lower forage to concentrate ratio, but NDF, acid detergent fiber, and hemicellulose digestibility were not affected. Corn silage had greater DM and NDF digestibility than SS. Also, fractional rate of digestion was faster for CS than SS (2.78 vs. $2.42 \%$ per hour, respectively). We conclude that fecal grab samples are suitable for predicting starch digestibility in heifers given the starch levels studied. In addition, SS was an adequate alternative forage in precision-fed dairy heifers with outcomes very similar to CS-based rations.
\end{abstract}

Received June 2, 2016.

Accepted August 28, 2016.

${ }^{1}$ Corresponding author: ajh@psu.edu
Key words: heifers, precision feeding, sorghum silage

\section{INTRODUCTION}

Climate change and variability have been very important topics for plant and animal agriculture. Climate change modifies crop yields, enabling nontraditional areas for some crop production while disabling others (Schlenker and Roberts, 2009). One way to adjust animal production is to use water-efficient crops, such as sorghum, that provide high yields of forage while consuming low quantities of water (30 to $50 \%$ lower than corn; Emile et al., 2006). Sorghum is becoming a reliable forage crop for silage in the United States as well as other areas around the world. Sorghum has low water requirement, excellent drought tolerance, high tonnage yield, and low fertility requirements. It has been shown to have high productivity under limited irrigation systems compared with corn. Furthermore, sorghum can be planted later than corn, and some varieties have regrowth ability, which may allow a second harvest within a single growing season. Cost of production of sorghum silage (SS) is lower compared with corn silage (CS), because SS requires fewer seeds, less fertilization (30\% lower than corn), and less irrigation (McCorkle et al., 2007).

Nutritionally, SS contains a higher proportion of protein, fiber, lignin, and ash but a lower proportion of starch compared with CS (McCorkle et al., 2007). Of course, variety, state of maturity, fermentation, and storage affect SS nutritional value. However, sorghum forage typically has lower DM digestibility compared with CS primarily because of the high lignin content. Lignin, the most indigestible part of a plant, limits ruminal and total-tract digestion. Corn plants usually have lower lignin content than sorghum, making CS more digestible than SS (Aydin et al., 1999; Oliver et al., 2004).

New varieties of sorghum have been selected to reduce undesirable characteristics and improve desirable ones, yielding plants with a lower proportion of tannins in grain (which indirectly decreases fiber digestibility), improved palatability, ability to withstand wind, ongoing high yields, reduced lignin content, and waxy en- 
dosperm in the grain that improves starch digestibility (Miron et al., 2007). Brown midrib (BMR) sorghum, which is classified as a newer variety, has lower lignin and fiber (NDF) content, which allows for improved DM digestibility and intake of this forage in ruminants. The BMR sorghum forage has nutritional composition comparable to CS and is a viable forage option for dairy rations (Aydin et al., 1999; Oliver et al., 2004).

In situ studies that compared SS, BMR sorghum, and CS found that BMR sorghum had higher NDF digestion than regular SS and CS (Grant et al., 1995; Di Marco et al., 2009). Some in vivo studies have reported milk production and DMI were higher in dairy cows consuming BMR sorghum compared with regular SS or CS (Aydin et al., 1999), but others saw no differences in DMI or milk yield (Oliver et al., 2004; Emile et al., 2006; Miron et al., 2007).

Because sorghum can be an important source of fiber and energy in ruminant nutrition and may be substituted for corn in many aspects, information needs to be available on the feeding and digestibility of this crop (Oliver et al., 2004). Therefore, additional research is required for the most efficient use of this crop in dairy diets. To our knowledge, no published research exists on the use of SS in a limit-fed diet for dairy heifers. Precision feeding, which relies on high-density nutrient diets that meet the needs of growing heifers by using highly digestible feedstuffs, is being widely used in the industry. With this type of diet, heifers can achieve higher than normal digestibility of feeds in the rumen and can reduce energy expenses associated with digestion of large volume of feeds (ad libitum diet) because of a reduction in visceral organ size and less oxygen consumption. Thus more dietary energy can be partitioned to growth instead of maintenance (Zanton and Heinrichs, 2009). This reduction in the metabolic expenses and the increase in rumen degradation of nutrients improves feed efficiency (Zanton and Heinrichs, 2016). The objective of this study was to evaluate totaltract nutrient utilization, ruminal environment, and digestibility parameters of precision-fed dairy heifers using BMR SS in different forage to concentrate ratios (FOR:CON). Additionally, we wanted to validate the use of rectal grab samples for estimating starch digestibility of heifer diets. We hypothesized that BMR SS would respond similarly to CS in precision-fed dairy heifer diets, with similar digestibility and fermentation parameters that will allow additional use of this crop in the dairy industry.

\section{MATERIALS AND METHODS}

All procedures involving the use of animals were approved by the Pennsylvania State University Institu- tional Animal Care and Use Committee (no. 46266). Eight Holstein heifers (13.7 \pm 0.6 mo of age and 364.8 $\pm 17.64 \mathrm{~kg}$ of BW) fitted with a $10-\mathrm{cm}$ silicone rumen cannula (Kehl, SP, Brazil) were used in a $4 \times 4$ Latin Square design with 19-d periods including $15 \mathrm{~d}$ of adaptation and $4 \mathrm{~d}$ of sampling. Treatments included 4 levels of FOR:CON (85:15, 75:25, 65:35, and 55:45) using SS as the forage source in a precision-feeding program.

Heifers were kept in tie-stalls for $40 \mathrm{~d}$ before the experiment (pretrial adaptation period to adapt heifers to the facility and management as well as to recover from the cannulation surgery) and were then randomly assigned to treatments. Heifers were weighed weekly, and BW was determined by the average of 2 measurements taken on the same day before feeding. The amount of TMR offered during the experiment was adjusted weekly based on BW to allow an average of 0.95 to 1.0 $\mathrm{kg} / \mathrm{d}$ of ADG. Heifers were housed in individual tiestalls and individually fed in a mechanically ventilated barn. Heifers had free access to water in the stalls. The animals were released to a paved exercise pen for 3.5 $\mathrm{h} / \mathrm{d}$ on nonsampling days.

Rations were mixed in a Calan Super Data Ranger (American Calan, Northwood, $\mathrm{NH}$ ) every $4 \mathrm{~d}$, and the diets were mixed prior to the $4 \mathrm{~d}$ of sampling to avoid variability. The different diets were kept in closed nylon bags to avoid oxygenation and stored in a cooler room until fed. Predicted DMI was calculated for each animal based on BW and energy intake. Grain mixes were formulated to provide the same energy level ( 0.23 Mcal of ME intake $/ \mathrm{kg}$ of empty $\mathrm{BW}^{0.75}$ ) in each diet, and $\mathrm{N}$ intake in the different FOR:CON diets ( $\mathrm{N}$ was balanced to $1.82 \mathrm{~g}$ of $\mathrm{N} / \mathrm{kg}$ of empty $\left.\mathrm{BW}^{0.75}\right)$. Grain mixes were prepared before each period as a single mix. Rations were fed daily as TMR at $1200 \mathrm{~h}$. Sorghum silage DM was measured every day of ration preparation in a microwave as described by Pino and Heinrichs (2014). Eating time (hours to consume the whole ration) was recorded daily during sampling days. Ration was considered totally consumed when less than $50 \mathrm{~g}$ remained in the feed bunk.

The variety of sorghum used in this study was an early BMR-6 brachytic dwarf (AF7102, Altaseed, Amarillo, TX). This variety was planted July 1 , and it could be harvested between 85 and $90 \mathrm{~d}$ after planting; brachytic dwarf genes provide stout stalks and good standability without compromising high yield and forage quality. This hybrid was recommended because its short growing season suits the area of Pennsylvania where it was to be grown. Unfortunately, planting was delayed because of late harvest of the previous crop (sorghum was double cropped following wheat), and the yield and quality were lower than expected. Sorghum was used as the only source of forage in the diets. 
Feedstuffs were collected before every period, and TMR was collected during the mixing day to be dried in a forced-air oven at $55^{\circ} \mathrm{C}$ for $48 \mathrm{~h}$ to measure $\mathrm{DM}$ and then ground through a 1-mm screen (Wiley mill, Arthur H. Thomas, Philadelphia, PA) for further analysis. Particle size was analyzed (Penn State Particle Separator with 19-, 8-, and 4-mm sieves) on mixing day using a composite of the diet to be fed each of the $4 \mathrm{~d}$ for each treatment.

Total collection of feces was used to estimate nutrient total-tract digestibility. Urine was collected from $\mathrm{d}$ 15 to 20 using the modified cup collector described by Lascano et al. (2010). Urine was acidified to $\mathrm{pH} 2$ by the addition of $1 \mathrm{~L}$ of $10 \% \mathrm{HCl}$ solution in an $18.9-\mathrm{L}$ bucket to minimize $\mathrm{NH}_{3}$ volatilization. During sampling days total urine was weighed, recorded, and subsampled daily after feeding. At the end of each period urine samples were composited, and a 150-mL subsample was frozen at $-20^{\circ} \mathrm{C}$ for further analysis.

During sampling days, feces were collected and stored in airtight containers. After feeding, daily feces were mixed and a subsample was saved at $4^{\circ} \mathrm{C}$ to be composited at the end of each period. The subsample was then dried in a forced-air oven at $55^{\circ} \mathrm{C}$ for $72 \mathrm{~h}$ and ground through a 1-mm screen (Wiley mill, Arthur H. Thomas).

The composited and dried feed and fecal samples were analyzed for DM and ash (AOAC International, 2000; methods 934.01 and 942.05, respectively); NDF and ADF were analyzed individually (Van Soest et al., 1991). Analysis of NDF included use of heat-stable $\alpha$-amylase (Sigma Chemical Co., St. Louis, MO) and sodium sulfite (Van Soest et al., 1991) using an Ankom $^{200}$ fiber analyzer (Ankom Technology Corp., Fairport, NY). Diet CP was calculated from CP of feedstuffs as analyzed by Cumberland Valley Analytical Services, Inc. (Maugansville, MD). Starch and soluble sugars were determined by the method of (Hall, 2009), using previously ground samples and Hazyme enzyme (Centerchem, Norwalk, CT). Metabolizable energy intake was estimated for each heifer within each period using the observed $\mathrm{OM}$ intake $\times 4.409 \times 0.82$ as described in NRC (2001).

Rumen fluid samples were taken on d 18 from 5 locations in the rumen (dorsal, ventral, anterior, caudal, and central) at $0,1,2,4,6,8,12,16,20$, and $22 \mathrm{~h}$ relative to feeding time. Rumen fluid was mixed and strained through a $0.28-\mathrm{mm}$ fiberglass mesh screen (New York Wire, Mt. Wolf, PA), $\mathrm{pH}$ was recorded ( $\mathrm{pH}$ meter, model M90, Corning Inc., Corning, NY), and strained fluid was placed in $10-\mathrm{mL}$ tubes with $5 \mathrm{~mL}$ of sample, $1 \mathrm{~mL} 0.6 \%$ 2-ethylbutyric, and $1 \mathrm{~mL}$ of $25 \%$ metaphosphoric acid at $-20^{\circ} \mathrm{C}$ for VFA analysis (Yang and Varga, 1989).
In situ DM and NDF degradability were evaluated for SS and compared with CS on d 20 of the last period, using the same diets fed during the sampling days. Samples were ground through a $2-\mathrm{mm}$ screen and put in $10 \times 20-\mathrm{cm}$ nylon Ankom bags (pore size 50 $\pm 15 \mu \mathrm{m}$; Ankom Technology Corp.) that were closed with zip ties in 2 different places. Eight grams of each sample was prepared in triplicate. Samples were placed in a laundry bag and tied with a cord to the cannulas. Bags were placed in warm distilled water for $15 \mathrm{~min}$ before being inserted in the rumen and were incubated for $96,72,48,36,24,16,12,8,4,2,1$, and $0 \mathrm{~h}$. All bags were removed $2 \mathrm{~h}$ post feeding and were separated and rinsed manually with tap water, then run through a 2-min rinse cycle in a washing machine 3 times. Bags were rolled and dried in a forced-air oven at $55^{\circ} \mathrm{C}$ for 72 h. Samples were then weighed to determine DM digestibility, and a subsample of $0.5 \mathrm{~g}$ was used to measure NDF digestibility. The proportion of indigestible NDF (iNDF) was determined by incubating silage samples for $12 \mathrm{~d}$ in the rumen. Ruminal NDF digestibility was calculated for SS and CS at 24 and $48 \mathrm{~h}$. The potential extent of NDF digestion (PED) was calculated as PED $=100 \times \mathbf{P d N D F} /(\mathrm{PdNDF}+\mathrm{iNDF})$; where potentially digestible NDF (PdNDF) is a proportion of the initial DM (NDF - iNDF) (Grant, 1994). Rate and extent of digestion and digestion lag time were calculated using the log-linear least square regression method described by Moore and Cherney (1986).

An additional objective of this study was to compare starch digestibility from total collection and to evaluate the potential of estimating starch digestibility from fecal grab samples at different time points. Four fecal grab samples (approximately $500 \mathrm{~g}$ ) were collected from the same 8 heifers previously described on sampling days (d 15-19) at $0,6,12$, and $18 \mathrm{~h}$ relative to feeding time and were composited by time. Also, a composite of all time points by treatment was created at the end of the period to compare and correlate with starch digestibility using the total collection fecal starch. The total amount collected per day was added to the total collection per day to avoid altering the digestibility analysis. The subsample was dried in a forced-air oven as previously described. Grab samples were taken at different time points to compare variation in the rate of excretion of starch in precision-fed heifers.

All statistical analyses were conducted in SAS (version 9.4, SAS Institute Inc., Cary, NC) using the MIXED procedure. Dependent variables were analyzed as a $4 \times 4$ Latin Square design with 2 heifers in each treatment. Heifers were considered experimental units because they were individually fed and intake and ADG were known. All denominator degrees of freedom for $\mathrm{F}$ - 
tests were calculated according to Kenward and Roger (1997).

The model used was

$$
\mathrm{Y}_{i j k=} \mu+\mathrm{S}_{i}+\mathrm{N}_{j}+\mathrm{P}_{k}+\mathrm{NP}_{(j k)}+\mathrm{SN}_{(i j)}+\mathrm{e}_{i j k},
$$

where $\mathrm{Y}_{i j k}$ is a continuous dependent response variable; $\mu$ is the overall mean; $\mathrm{S}_{i}$ is the fixed effect of FOR:CON $(i=1,2,3,4) ; \mathrm{N}_{j}$ is the random effect of heifer; $\mathrm{P}_{k}$ is the period effect; $\mathrm{NP}_{(j k)}$ is the heifer by period interaction; $\mathrm{SN}_{(i j)}$ is the heifer by FOR:CON treatment interaction, and $\mathrm{e}_{i j k}$ is the residual error. All nonsignificant interactions were removed from the model $\left[\mathrm{NP}_{(j k)}\right.$ $\left.+\mathrm{SN}_{(i j)}\right]$. Repeated measures were used to analyze $\mathrm{pH}$ and VFA using the spatial power covariance structure for time intervals that were not evenly spaced; repeated measures of digestibility data used compound symmetry covariance structure. Time and time $\times$ treatment interaction were included in the model for all repeated measures. In the in situ study, FOR:CON was included as a covariate in the model. All comparison data for fecal starch were analyzed by multiple linear regression utilizing starch digestibility (with the total collection fecal starch) as the dependent variable and fecal starch at each time, heifer, period, and FOR:CON as independent variables. Residual variances were assumed to be normally distributed, and all data are presented as least squares means. $P$-values for linear and quadratic effects and their interactions were analyzed using orthogonal polynomial contrasts. Differences were declared significant at $P \leq 0.05$ and tendencies at $P \leq 0.10$ for main effects.

\section{RESULTS AND DISCUSSION}

Diet ingredients, chemical composition of individual ingredients, and particle size are presented in Table 1. Ingredients were analyzed for each period to report composition of the diets. Sorghum silage averaged 8.2\% CP, $62.95 \%$ NDF, $38.10 \%$ ADF, and 2.35 Mcal of ME/ $\mathrm{kg}$ during the 4 periods. Quality of the sorghum was lower than expected, likely due to late planting and season, resulting in the starch content being lower than expected. Rations were formulated in a precision-feeding program to provide equal $\mathrm{ME} / \mathrm{kg}$ of $\mathrm{BW}^{0.75}$ with different FOR:CON (85:15, 75:25, 65:35, and 55:45\%; DM basis). Diets were formulated with the same CP content for all the treatments. Neutral detergent fiber, $\mathrm{ADF}$, and hemicellulose were gradually decreased, while starch and energy (ME) increased as concentrate increased in the diet. Particle size distribution changed to lower proportions in the $19-\mathrm{mm}$ sieve and higher proportions in the 4-mm sieve as concentrate increased in the ration, as would be expected.
The FOR:CON did not affect ADG, and no differences were observed in average BW of heifers during the course of the experiment (Table 2). Dry matter intake, as kilograms of $\mathrm{BW}^{0.75}$ and as percentage of $\mathrm{BW}$, decreased linearly as concentrate increased in the ration because the intake of the different FOR:CON rations was based on energy intake $(P \leq 0.01$ and $P$ $=0.03$, respectively); therefore, as the concentrate increased, diets were more energy dense, with decreasing DMI to allow the same ME/kg of BW ${ }^{0.75}$. Because DMI was lower when concentrate was increased and ADG was similar, feed efficiency tended to increase linearly as the concentrate proportion was higher in the ration $(P=0.08)$. Increased concentrate proportion in the diet resulted in a linear decrease in NDF, ADF, and hemicellulose intakes, and starch intake was higher. As planned, $\mathrm{CP}$ and ME intake were not affected by treatment.

\section{VFA and Rumen Fermentation}

Total VFA and VFA concentrations are presented in Table 3, and variation of VFA concentration over time is presented in Figure 1. Overall, total VFA concentrations were not different by treatment; however, between 2 and $6 \mathrm{~h}$ after feeding, total VFA was lower in the diets with high proportions of forage (FOR:CON 85:15; $P \leq$ 0.05; Figure 1A). Also, total VFA for the FOR:CON $85: 15$ diet, was higher than the others at 16 to $24 \mathrm{~h}$ after feeding $(P \leq 0.05)$. This effect was attributed to heifers spending more time consuming the ration, resulting in a slower fermentation in the first hours after feeding. Total VFA concentration was lower compared with previous studies with similar FOR:CON (60:40) (Calsamiglia et al., 2008; Lascano, 2011); however, Lascano and Heinrichs (2009) reported no variation in total VFA concentration with similar FOR:CON as the current study diets, but using CS-based diets. A treatment by time interaction was detected for total VFA $(P \leq 0.01)$, suggesting that the time of fermentation of nutrients was different and the rate of digestion of forages was prolonged over time.

Acetate proportion was not different by treatment but was higher for the FOR:CON 85:15 diet between 2 and $4 \mathrm{~h}$ after feeding (Figure $1 \mathrm{~B}, P \leq 0.05$ ) in comparison with the FOR:CON 65:35 and FOR:CON 55:45 treatments. These results were different from Lascano (2011), in which acetate proportion was higher in diets with high FOR:CON. In the current study, the higher acetate proportion of the FOR:CON 85:15 at 2 to $4 \mathrm{~h}$ after feeding may be due to changes in $\mathrm{pH}$ experienced during that time point explained by the lower eating rate. Propionate proportion was not different by treatment but had a lower proportion for the FOR:CON 
Table 1. Ingredient and chemical composition (\% of DM unless otherwise noted) of treatment rations offered containing 4 different forage to concentrate ratios (FOR:CON)

\begin{tabular}{|c|c|c|c|c|}
\hline \multirow[b]{2}{*}{ Item } & \multicolumn{4}{|c|}{ FOR:CON } \\
\hline & $85: 15$ & $75: 25$ & $65: 35$ & $55: 45$ \\
\hline \multicolumn{5}{|l|}{ Ingredient } \\
\hline Sorghum silage & 85 & 75 & 65 & 55 \\
\hline Ground corn & 9.40 & 18.27 & 27.18 & 36.10 \\
\hline Canola meal & 2.03 & 3.18 & 4.30 & 5.40 \\
\hline Optigen $^{1}$ & 1.87 & 1.85 & 1.82 & 1.80 \\
\hline Mineral mix $^{2}$ & 1.70 & 1.70 & 1.70 & 1.70 \\
\hline \multicolumn{5}{|l|}{ Chemical composition } \\
\hline DM, $\%$ & 30.78 & 33.95 & 37.14 & 41.67 \\
\hline $\mathrm{CP}$ & 13.91 & 13.80 & 14.12 & 14.09 \\
\hline $\mathrm{NDF}$ & 55.75 & 51.15 & 46.52 & 41.88 \\
\hline $\mathrm{ADF}$ & 33.29 & 30.03 & 26.77 & 23.50 \\
\hline Hemicellulose $^{3}$ & 22.46 & 21.12 & 19.75 & 18.38 \\
\hline Starch & 8.25 & 15.12 & 21.91 & 28.70 \\
\hline $\mathrm{ME},{ }^{4} \mathrm{Mcal} / \mathrm{kg}$ of $\mathrm{DM}$ & 2.39 & 2.46 & 2.53 & 2.60 \\
\hline $\mathrm{ME},{ }^{5} \mathrm{Mcal} / \mathrm{kg}$ of $\mathrm{BW}^{0.75}$ & 0.20 & 0.20 & 0.20 & 0.20 \\
\hline $\mathrm{Ca}$ & 0.55 & 0.52 & 0.49 & 0.47 \\
\hline $\mathrm{P}$ & 0.24 & 0.25 & 0.27 & 0.28 \\
\hline $\mathrm{K}$ & 0.12 & 0.21 & 0.30 & 0.39 \\
\hline $\mathrm{Na}$ & 0.08 & 0.08 & 0.08 & 0.08 \\
\hline $\mathrm{S}$ & 0.03 & 0.05 & 0.07 & 0.08 \\
\hline \multicolumn{5}{|l|}{ Particle size $^{6}$} \\
\hline$>19.0 \mathrm{~mm}$ & 12.46 & 12.82 & 9.21 & 6.06 \\
\hline 19.0 to $8.0 \mathrm{~mm}$ & 56.98 & 54.62 & 48.99 & 46.66 \\
\hline 8.0 to $4.0 \mathrm{~mm}$ & 10.70 & 9.79 & 11.53 & 9.93 \\
\hline$<4.0 \mathrm{~mm}$ & 19.87 & 22.77 & 30.27 & 37.35 \\
\hline
\end{tabular}

${ }^{1}$ Slow-release urea (Alltech, Nicholasville, KY) contains $94.8 \%$ DM and $269.9 \%$ CP.

${ }^{2}$ Mineral mix (US Feeds Inc., Eldora, IA) contains $94.28 \%$ DM, $11.65 \%$ CP, $1.7 \%$ soluble CP, $5.46 \%$ RUP, $8.29 \%$ ADF, $19.2 \% \mathrm{NDF}, 5.5 \%$ fat, $12.4 \% \mathrm{Ca}, 0.36 \% \mathrm{P}, 2.63 \% \mathrm{Mg}, 0.44 \% \mathrm{~K}, 0.39 \% \mathrm{~S}, 1,628.87 \mathrm{mg} / \mathrm{kg} \mathrm{Mn}$, $542.71 \mathrm{mg} / \mathrm{kg} \mathrm{Cu}, 1,639 \mathrm{mg} / \mathrm{kg} \mathrm{Zn}, 232.94 \mathrm{mg} / \mathrm{kg} \mathrm{Fe}, 9.90 \mathrm{mg} / \mathrm{kg} \mathrm{Se}, 9.2 \mathrm{mg} / \mathrm{kg} \mathrm{Co}, 22.2 \mathrm{mg} / \mathrm{kg} \mathrm{I}, 70.748 \mathrm{IU} / \mathrm{g}$ vitamin A, $17.637 \mathrm{IU} / \mathrm{g}$ vitamin $\mathrm{D}$, and $1.230 \mathrm{IU} / \mathrm{g}$ vitamin $\mathrm{E}$.

${ }^{3}$ Hemicellulose $=$ NDF - ADF.

${ }^{4} \mathrm{ME}$ calculated as TDN $\times 0.04409 \times 0.82$.

${ }^{5} \mathrm{ME}$ in $\mathrm{Mcal} / \mathrm{kg}$ of metabolic BW.

${ }^{6}$ Measured with the Penn State Particle Separator.

Table 2. Body weight, DMI, ADG, feed efficiency, and nutrient intake containing 4 different forage to concentrate ratios (FOR:CON)

\begin{tabular}{|c|c|c|c|c|c|c|c|c|}
\hline Item & \multicolumn{4}{|c|}{ FOR:CON } & SEM & \multicolumn{3}{|c|}{ Contrast, $P$-value } \\
\hline$\overline{\mathrm{BW}},^{2} \mathrm{~kg}$ & 390.80 & 389.78 & 386.57 & 385.40 & 6.02 & 0.71 & 0.26 & 0.98 \\
\hline DMI, $\mathrm{kg} / \mathrm{kg}$ of $\mathrm{BW}^{0.75}$ & 7.291 & 7.119 & 6.928 & 6.726 & 0.91 & $<0.01$ & $<0.01$ & 0.66 \\
\hline DMI, \% BW & 1.87 & 1.83 & 1.79 & 1.74 & 0.03 & 0.03 & $<0.01$ & 0.86 \\
\hline $\mathrm{NDF}, \mathrm{kg} / \mathrm{d}$ & 4.067 & 3.652 & 3.230 & 2.829 & 0.03 & $<0.01$ & $<0.01$ & 0.70 \\
\hline $\mathrm{ADF}, \mathrm{kg} / \mathrm{d}$ & 2.427 & 2.142 & 1.858 & 1.560 & 0.02 & $<0.01$ & $<0.01$ & 0.52 \\
\hline Hemicellulose, ${ }^{4} \mathrm{~kg} / \mathrm{d}$ & 1.640 & 1.510 & 1.371 & 1.243 & 0.02 & $<0.01$ & $<0.01$ & 0.93 \\
\hline Starch, kg/d & 0.601 & 1.077 & 1.518 & 1.931 & 0.02 & $<0.01$ & $<0.01$ & 0.30 \\
\hline $\mathrm{CP}, \mathrm{kg} / \mathrm{d}$ & 0.993 & 0.991 & 0.992 & 0.989 & 0.09 & 0.11 & $<0.01$ & 0.02 \\
\hline $\mathrm{ME},{ }^{5} \mathrm{Mcal} / \mathrm{d}$ & 17.409 & 17.526 & 17.538 & 17.498 & 0.21 & 0.72 & 0.48 & 0.38 \\
\hline
\end{tabular}

${ }^{1} \mathrm{~L}=$ linear; $\mathrm{Q}=$ quadratic.

${ }^{2}$ Average BW for the experiment.

${ }^{3} \mathrm{~kg}$ of DMI $/ \mathrm{kg}$ of ADG.

${ }^{4}$ Hemicellulose $=$ NDF - ADF.

${ }^{5} \mathrm{ME}$ calculated as TDN $\times 0.04409 \times 0.82$. 
$85: 15$ diet between 2 and $4 \mathrm{~h}$ after feeding in comparison to the other diets (Figure 1C; $P \leq 0.05$ ). Similar results were observed by Pino and Heinrichs (2016) with different levels of starch in the diets. A treatment by time interaction was detected for total propionate proportion $(P \leq 0.05)$. However, butyrate increased linearly as the concentrate proportion increased in the ration $(P=0.05$; Figure $1 \mathrm{D})$. In this study, butyrate proportion increased more in the high concentrate diet (FOR:CON 55:45) at the expense of acetate. In previous experiments in which the FOR:CON was modified, if $\mathrm{pH}$ was maintained above 6.2 , the butyrate proportion increased as the concentrate increased (Fuentes et al., 2009; Ramos et al., 2009). A treatment by time interaction was detected for total butyrate proportion $(P \leq 0.01)$. Valerate and isovalerate decreased linearly as the concentrate proportion increased in the $\operatorname{diet}(P$ $\leq 0.01$ and 0.02, respectively). Joshi and Herdt (2006) stated that as iNDF increases in the rumen, the rate of passage slows, decreasing the rate of absorption of valerate and isovalerate. This pattern could explain why valerate and isovalerate were higher in the high forage diets in this study. These results are the opposite of those shown by Zanton and Heinrichs (2008) and Lascano and Heinrichs (2009), who found that valerate and isovalerate increased when the proportion of concentrates was higher. Acetate to propionate ratio was not affected by treatment.

Rumen $\mathrm{pH}$, rate of feed consumption, and the time that heifers spent consuming the meal are presented in Table 3 and Figure 1E. Mean and minimum pH decreased linearly as the proportion of concentrate increased ( $P \leq 0.01$ in both cases). It is important to note that the minimum $\mathrm{pH}$ found was 5.7 in the $55: 45$ FOR:CON diet (36\% starch), which is still acceptable to provide an adequate rumen environment and will not likely affect the ability of rumen fibrolytic bacteria populations to modify fiber digestion because of the limited time that rumen $\mathrm{pH}$ was under 6.0 (Van Soest, 1994). This lower $\mathrm{pH}$ is related to the higher butyrate proportion presented in the 55:45 FOR:CON diet (Table 3) and the reduced time that heifers spent consuming the whole ration. These results are similar to previous studies (Pino and Heinrichs, 2016), in which higher concentrations of starch modified the butyrate proportion as well as the rumen $\mathrm{pH}$. Maximum $\mathrm{pH}$ was not affected by treatment. Higher concentrate diets, principally high in starch, did not affect rumen $\mathrm{pH}$ in heifers with a precision-feeding program.

Eating time was decreased as concentrate increased (3.4 vs. $15.3 \mathrm{~h}$ for low and high forage diets; $P \leq 0.01$ ). These effects are a consequence of reduced fiber and

Table 3. Rumen $\mathrm{pH}$, eating time, rate of eating, total VFA, VFA proportion, and digestibility for heifers fed 4 different forage to concentrate ratios (FOR:CON)

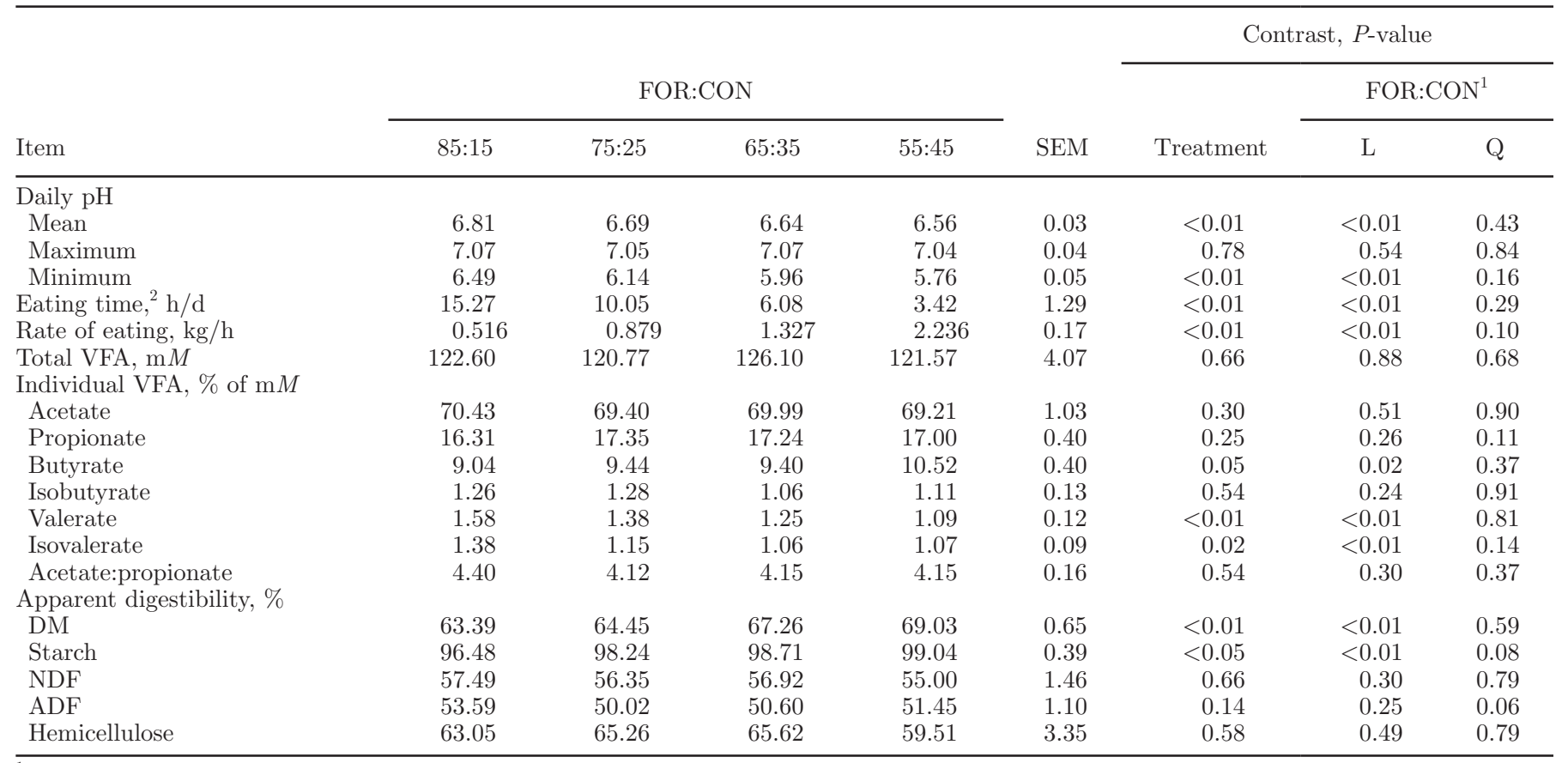

${ }^{1} \mathrm{~L}=$ linear; $\mathrm{Q}=$ quadratic.

${ }^{2}$ Eating time calculated from feeding to completion of the meal. 

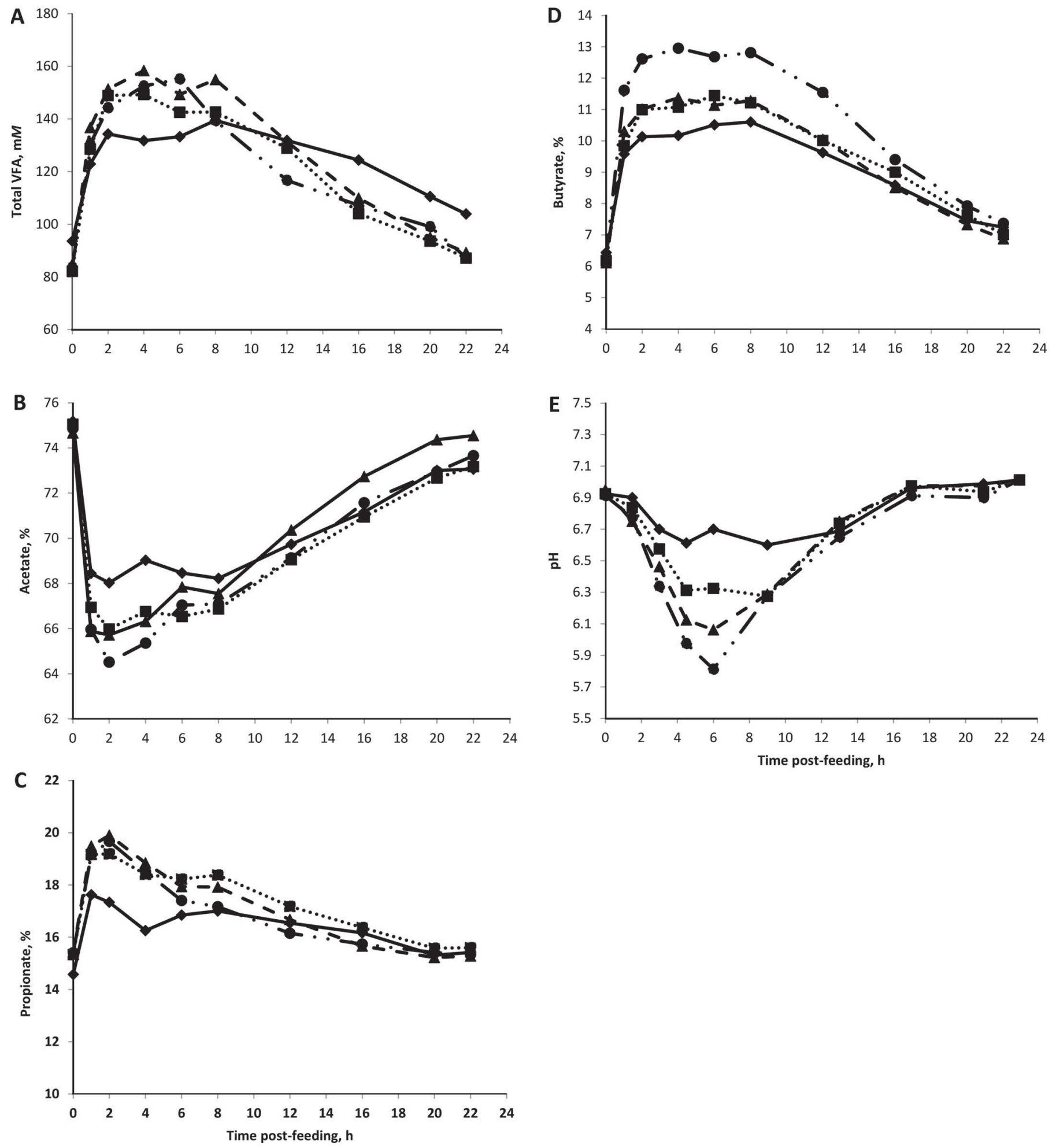

Figure 1. Fermentation end products over $24 \mathrm{~h}$ in precision-fed heifers with 4 forage to concentrate ratios (FOR:CON). (A) Total VFA, $\mathrm{m} M$, FOR:CON $\times$ time interaction $P \leq 0.01 ;(\mathrm{B})$ acetate, $\%, \mathrm{FOR}: \mathrm{CON} \times$ time interaction $P=0.37 ;(\mathrm{C})$ propionate, $\%, \mathrm{FOR}: \mathrm{CON} \times$ time interaction $P=0.05$; (D) butyrate, $\%, \overline{F O R}: C O N \times$ time interaction $P \leq 0.01$; (E) rumen $\mathrm{pH}$ over $24 \mathrm{~h}$. 
Table 4. Excretion parameters in precision-fed heifers for heifers fed 4 different forage to concentrate ratios (FOR:CON)

\begin{tabular}{|c|c|c|c|c|c|c|c|c|}
\hline Item & \multicolumn{4}{|c|}{ FOR:CON } & SEM & \multicolumn{3}{|c|}{ Contrast, $P$-value } \\
\hline Wet feces, $\mathrm{kg} / \mathrm{d}$ & 18.66 & 17.96 & 15.81 & 13.53 & 0.49 & $<0.01$ & $<0.01$ & 0.12 \\
\hline Dry feces, $\mathrm{kg} / \mathrm{d}$ & 2.64 & 2.46 & 2.20 & 2.16 & 0.06 & $<0.01$ & $<0.01$ & 0.27 \\
\hline Urine, $\mathrm{kg} / \mathrm{d}$ & 9.17 & 9.40 & 9.33 & 12.59 & 2.27 & 0.17 & 0.07 & 0.23 \\
\hline
\end{tabular}

${ }^{1} \mathrm{~L}=$ linear; $\mathrm{Q}=$ quadratic.

${ }^{2}$ Feces included on as-is (wet) basis.

likely better palatability of the high concentrate diets. We previously observed similar results with diets high in starch and the same level of forage in the ration (Pino and Heinrichs, 2016).

\section{Nutrient Digestibility}

Apparent total-tract nutrient digestibility is presented in Table 3. Dry matter and starch digestibility increased linearly as the proportion of concentrate increased in the diet $(P \leq 0.01$ and $\leq 0.05$, respectively). High concentrate diets resulted in a DM digestibility of 69.21 vs. $63.39 \%$ in the high forage diets. Apparent DM digestibility of diets with FOR:CON 55:45 was higher than studies with the similar FOR:CON (Lascano, 2011; Pino and Heinrichs, 2016) using FOR:CON 60:40 diets. The higher DMI in heifers fed with FOR:CON 85:15 has been noted to increase rate of passage and reduce rate of digestion in heifers (Zanton and Heinrichs, 2008). In precision feeding diets, as heifers decrease DMI, rumen retention time increases, which allows longer digestion time for ruminal bacteria to degrade nutrients. Thus, high concentrate diets present higher digestibilities (Zanton and Heinrichs, 2016). This information agrees with data presented by Mertens and Loften (1980) and by Colucci et al. (1989), who found that high forage diets increase ruminal passage rate because of higher rumen load and also decrease rumen digestion. In a review, Zanton and Heinrichs (2009) stated that a higher proportion of forages in the diet decrease digestibility. In addition, high concentrate diets stimulate amylolytic bacteria and promote DM and starch digestion (Little et al., 1958; Brown et al., 2006; Moody et al., 2007). Neutral detergent fiber, ADF, and hemicellulose were not affected by treatment in the present study. These results are different from other studies with varying FOR:CON, in which a higher proportion of concentrate improved NDF, ADF, and hemicellulose digestion (Merchen et al., 1986; Moody et al., 2007). Also in studies using sorghum forage for lactating dairy cows fed higher rates of DMI, NDF and ADF digestion were lower than in the current study (Aydin et al., 1999).

Manure excretion data are presented in Table 4. Wet and dry feces decreased linearly as the proportion of concentrate increased in the diet $(P \leq 0.01)$. In this study, urine and total manure production did not differ by FOR:CON. It has been speculated that precision-fed heifers in a tie-stall environment may consume more water and therefore produce more urine as a possible consequence of these combined situations (DeVries and von Keyserlingk, 2009; Greter et al., 2011). As shown previously, manure production is highly correlated with DMI and digestion. In this study, heifers on the FOR:CON 85:15 diet produced $5.13 \mathrm{~kg}$ more wet feces and $0.485 \mathrm{~kg}$ more dry feces in comparison with heifers fed the FOR:CON 55:45 diet $(P \leq 0.01)$, as is often observed in precision or limit feeding (Zanton and Heinrichs, 2008; Lascano et al., 2009; Pino and Heinrichs, 2016).

Overall, studies have shown that the new varieties of SS have very acceptable performance outcomes in dairy diets. Studies have demonstrated that BMR SS has similar digestibility in comparison with CS (Oliver et al., 2004). Even if starch digestibility is lower than CS, SS can provide enough energy for use in dairy rations without affecting milk production (Aydin et al., 1999). In the case of precision-fed dairy heifers, the outcome is very acceptable. Because the DMI is lower, the rumen retention time that heifers have for digesting fiber is higher; consequently, the total-tract digestibility should be higher (Mertens, 2005; Zanton and Heinrichs, 2008). This situation could be different with ad libitum diets, in which rate of passage is often increased and digestion decreased (Mertens and Loften, 1980).

\section{In Situ Degradability and Rumen Kinetics}

Dry matter and NDF in situ degradability (DMD and NDFD, respectively) are presented in Table 5 and Figure 2. Sorghum silage had $65.67 \%$ of NDF vs. 


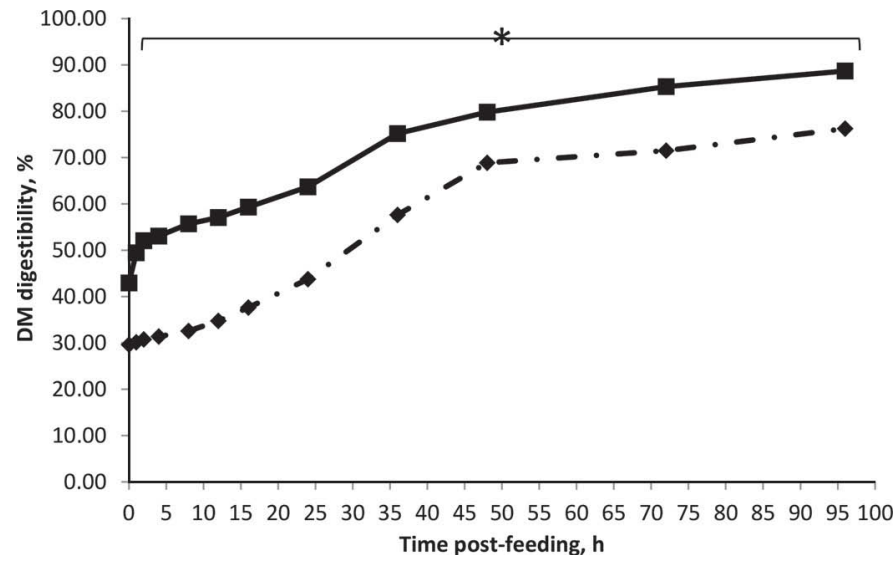

Figure 2. In situ DM digestibility over time comparing corn (solid line) versus sorghum silage (dashed line). ${ }^{*}$ Values at all timepoints differed at $P<0.05$.

$39.81 \%$ of NDF of CS (DM basis). In this study, SS contained approximately 15\% more NDF than is often observed in BMR SS. In Figure 2, DMD is shown to be lower for SS than for CS over time $(P \leq 0.05)$. At $24 \mathrm{~h}$ of DM digestion, SS was $18.5 \%$ less digestible than CS $(P \leq 0.01), 11 \%$ less digestible at $48 \mathrm{~h}(P \leq 0.01)$, and $13.8 \%$ less digestible at $72 \mathrm{~h}(P \leq 0.01$; Table 5$)$. This outcome could be explained by the high NDF in SS and lower digestibility of the fiber.

At $24 \mathrm{~h}, \mathrm{DMD}$ for SS linearly decreased as the proportion of concentrate increased in the diet $(P=0.05$; Table 5). Also, DMD of CS showed a quadratic effect as the proportion of concentrate increased in the diet $(P$ $\leq 0.05)$ and was higher in diets with 25 or $35 \%$ concentrate. In addition, SS linearly decreased at $24 \mathrm{~h}$ NDFD $(P \leq 0.05)$ but $\mathrm{CS}$ did not show any difference, being higher for FOR:CON 55:45 ( $P \leq 0.01)$. At 48 h, DMD for SS was higher in FOR:CON 75:25 and CS showed a quadratic effect being higher in FOR:CON 75:25 and 65:35 $(P \leq 0.05)$. Sorghum silage showed a lower NDFD at $48 \mathrm{~h}$ for FOR:CON 85:25 compared with the other diets; however, CS increased linearly when the concentrate portion of the diet increased $(P \leq 0.05)$. These results suggest that as more concentrate was fed, DMD and NDFD improved for CS. This finding agrees with previous studies in which rumen bacteria population increased and improved digestion as the portion of concentrate increased in the diets (Sarwar et al., 1991; Pino and Heinrichs, 2016). In the present study, 48-h NDFD was higher compared with an in vivo study done by (Oliver et al., 2004), but similar to an in situ BMR sorghum study (Di Marco et al., 2009).

Table 5. In situ degradability comparing sorghum versus corn silage at 4 different forage to concentrate ratios (FOR:CON)

\begin{tabular}{|c|c|c|c|c|c|c|c|c|}
\hline \multirow[b]{2}{*}{ Item } & \multicolumn{4}{|c|}{ FOR:CON } & \multirow[b]{2}{*}{ SEM } & \multicolumn{3}{|c|}{ Contrast, $P$-value } \\
\hline & $85: 15$ & $75: 25$ & $65: 35$ & $55: 45$ & & Treatment & $\mathrm{L}$ & $\mathrm{Q}$ \\
\hline \multicolumn{9}{|l|}{$24-\mathrm{h} \mathrm{DMD}{ }^{2} \%$} \\
\hline Sorghum silage & $46.45^{\mathrm{a}}$ & $45.00^{\mathrm{ab}}$ & $44.21^{\mathrm{b}}$ & $43.89^{\mathrm{c}}$ & 0.31 & 0.06 & 0.05 & 0.35 \\
\hline Corn silage & $63.88^{\mathrm{a}}$ & $62.81^{\mathrm{ab}}$ & $61.89^{\mathrm{b}}$ & $64.98^{\mathrm{c}}$ & 0.70 & 0.23 & 0.45 & 0.11 \\
\hline Corn silage & $77.73^{\mathrm{a}}$ & $82.30^{\mathrm{b}}$ & $81.67^{\mathrm{b}}$ & $78.26^{\mathrm{a}}$ & 0.23 & 0.10 & 0.05 & 0.28 \\
\hline \multicolumn{9}{|l|}{$24-\mathrm{h} \mathrm{NDFD}^{3} \%$} \\
\hline Sorghum silage & $38.04^{\mathrm{a}}$ & $36.17^{\mathrm{b}}$ & $33.66^{\mathrm{c}}$ & $30.64^{\mathrm{c}}$ & 1.37 & 0.04 & 0.01 & 0.25 \\
\hline Corn silage & $32.78^{\mathrm{a}}$ & $31.71^{\mathrm{a}}$ & $32.05^{\mathrm{a}}$ & $36.75^{\mathrm{b}}$ & 0.81 & 0.21 & 0.50 & 0.18 \\
\hline \multicolumn{9}{|l|}{ 48-h NDFD \% } \\
\hline Sorghum silage & $63.04^{\mathrm{a}}$ & $66.55^{\mathrm{b}}$ & $64.36^{\mathrm{ab}}$ & $65.79^{\mathrm{ab}}$ & 0.61 & 0.12 & 0.25 & 0.18 \\
\hline Corn silage & $59.15^{\mathrm{a}}$ & $65.96^{\mathrm{b}}$ & $65.64^{\mathrm{b}}$ & $69.84^{\mathrm{c}}$ & 0.81 & 0.07 & 0.04 & 0.35 \\
\hline Corn silage & $0.027^{\mathrm{a}}$ & $0.029^{\mathrm{b}}$ & $0.030^{\mathrm{c}}$ & $0.028^{\mathrm{b}}$ & 0.01 & 0.05 & 0.12 & 0.05 \\
\hline
\end{tabular}

\footnotetext{
${ }^{\mathrm{a}-\mathrm{c}}$ Means with different superscripts in a row differ at $P \leq 0.05$.

${ }^{1} \mathrm{~L}=$ linear; $\mathrm{Q}=$ quadratic.

${ }^{2}$ In situ DM digestibility.

${ }^{3}$ In situ NDF digestibility at 24 to $48 \mathrm{~h}$ of rumen fermentation.

${ }^{4}$ Potential extent of NFD digestion at $96 \mathrm{~h}$ of in situ fermentation.

${ }^{5} \mathrm{~K}_{\mathrm{d}}=$ fractional rate of digestion, $\% / \mathrm{h}$, where $Y=U+D \times \mathrm{e}^{-k(t-\operatorname{lag})}$, for $t>$ lag, where $U=$ undegradable fraction; $D=$ potentially degradable fraction; $t=$ time; $k=$ rate of digestion; lag = lag time (Grant, 1994).
} 
In comparison with this study, Di Marco et al. (2009) showed higher DMD at $24 \mathrm{~h}$ and lower DMD at $48 \mathrm{~h}$ using in situ and in vitro studies of BMR sorghum. However, Aydin et al. (1999) showed similar DMD compared with this study using BMR sorghum. Di Marco et al. (2009) stated that in situ DMD overestimates digestion at $48 \mathrm{~h}$ as compared with in vivo analysis in BMR sorghum and other feedstuffs. This conclusion supported results from Oba and Allen (2000), who concluded that the best time points to evaluate in situ degradation of CS were 24 and $30 \mathrm{~h}$ post feeding. In addition, Di Marco et al. (2002) found that the best time to predict DMD for CS was at $24 \mathrm{~h}$. Given all this information, more studies are required to compare CS vs. BMR sorghum degradation in situ analysis.

Potential digestible NDF and PED of NDF at 96 $\mathrm{h}$ are presented in Table 5. The PdNDF was $52.72 \%$ for SS and $60.09 \%$ for CS. Also, PED was higher for SS in FOR:CON 75:25, indicating that the diets with this proportion of concentrate in this study had greater potential to be digested in $96 \mathrm{~h}$. We did not observe differences in PED of NDF between the different FOR:CON diets. Sorghum silage PED was similar to the results of Oliver et al. (2004) and lower than Aydin et al. (1999); however, CS showed higher values than previous reports (Aydin et al., 1999; Oliver et al., 2004; Di Marco et al., 2009).

Fractional rates of digestion and lag time are presented in Table 5. These parameters were calculated using a model for fiber kinetics described by Moore and Cherney (1986) in which data were fit to a single exponential decay function using the nonlinear modeling procedure. The rate of digestion of NDF $\left(\mathbf{K}_{\mathbf{d}}\right)$ was higher for CS than SS $2.85 \%$ per hour vs. $2.42 \%$ per hour, respectively; $P \leq 0.01)$. The $\mathrm{K}_{\mathrm{d}}$ for $\mathrm{SS}$ showed a quadratic effect as the proportion of concentrate increased in the diet $(P \leq 0.05)$ and was lower with high and low forage diets (FOR:CON 85:15 and 55:45). However, CS had a linear increase in $K_{d}$ as the concentrate increased in the diet and was lower with high forage diets. Our results show a lower $\mathrm{K}_{\mathrm{d}}$ in comparison with other in situ kinetic studies using corn and sorghum BMR (Aydin et al., 1999; Oliver et al., 2004) but a higher $\mathrm{K}_{\mathrm{d}}$ than the results showed by Di Marco et al. (2009) in an in situ study. In this study, we calculated a similar rate of digestion compared with studies using normal or grain sorghum in which the NDF of forage was around 55 to 58\% (Grant, 1994; Aydin et al., 1999; Oliver et al., 2004). We speculate that the high proportion of NDF present in SS affected $\mathrm{K}_{\mathrm{d}}$ and digestion parameters.

Lag time was 0 for all FOR:CON; Mertens (2005) reported the same situation for some forages, indicating that instantaneous solubilization occurred. These results are the same as other studies comparing BMR SS with CS (Oliver et al., 2004). Summarizing the results of this study, we suggest that the lower DM, NDF, and $\mathrm{K}_{\mathrm{d}}$ presented in this study are related to the high NDF of SS because of the late planting and harvesting in the season, which decreased digestion and the nutritional value of this crop.

Fecal starch and $\mathrm{R}^{2}$ of starch digestibility with fecal starch at different time points of the fecal grab samples are presented in Figure 3. With the wide range of starch concentration used in this study, the data had a good fit. The equation included heifer, time, period, FOR:CON, and fecal starch at different times regressed with starch digestibility using total collection as the independent variable. All the variables included in the model were significant $(P \leq 0.05)$. The best relationship observed in this study was with fecal starch at $0 \mathrm{~h}$ after feeding time $\left(\mathrm{R}^{2}=0.85\right)$; however, all fecal time points were highly correlated with total starch levels. The best $\mathrm{R}^{2}$ was different than that presented by Fredin et al. (2014) who found that $12 \mathrm{~h}$ after feeding was the best time to predict starch digestibility in cows. In the case of the heifers, it is important to state that precision feeding could change the rate of digestion of starch in the rumen. The $\mathrm{R}^{2}$ of 0.85 was lower than other studies that used a similar method of estimating starch digestibility: Fredin et al. (2014), $\mathrm{R}^{2}=0.94$ in cows; Corona et al. (2005), $\mathrm{R}^{2}=0.97$; and Zinn et al. (2007) $\mathrm{R}^{2}=0.94$ in steers; but better than Owens and Zinn (2005), $\mathrm{R}^{2}=0.73$ in dairy cows. The best fit in this trial was in the FOR:CON 55:45 diet. Grant et al. (1995) showed that a direct relationship existed with the amount of NDF and the prediction of starch digestibility in dry cows, when diet NDF is higher and the $R^{2}$ between fecal starch and starch digestibility is

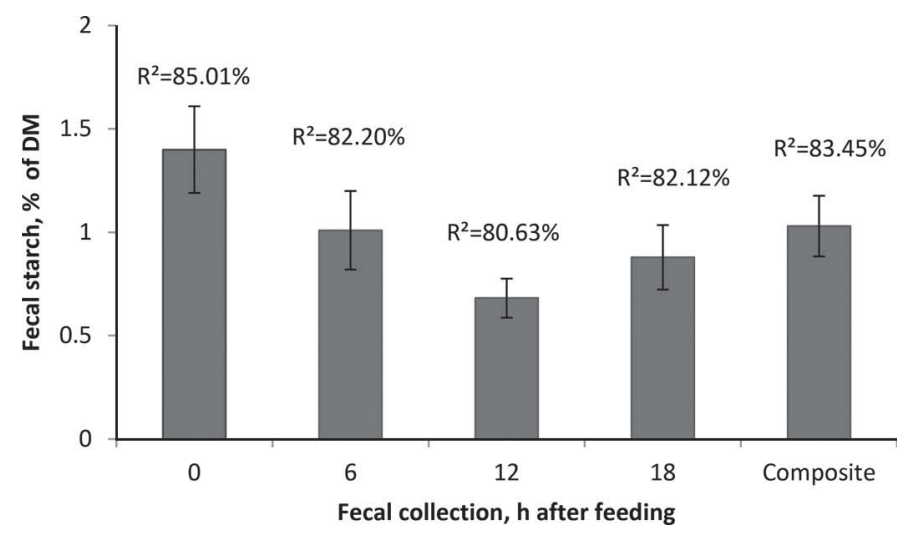

Figure 3. Effect of different time of fecal collection on fecal starch concentration. $\mathrm{R}^{2}$ values were determined for regression of starch digestibility (using total collection fecal starch, $0.82 \%$ average for all forage to concentrate ratios) versus fecal starch at each sampling time or for a composite created from all sampling times. All $P$-values were $<0.01$. 
lower. The effect of the time of collection of the fecal samples in this study was similar to results presented by Fredin et al. (2014), who observed variation in fecal starch among the times sampled and also presented a higher fecal starch at $0 \mathrm{~h}$ and a lower concentration at $12 \mathrm{~h}$ post feeding. All starch values here were quite high and had little variability, thus making any time point reasonably well correlated with the total daily starch level.

\section{CONCLUSIONS}

When the concentrate proportion of the diet increased, heifers tended to improve feed efficiency, primarily because of lower DMI with the same ADG over diets with a high proportion of forage in the diet. Rumen $\mathrm{pH}$ was affected by FOR:CON, decreasing as the proportion of concentrate increased in the diet and also because heifers spent less time consuming the meal. However, $\mathrm{pH}$ was never under 5.7 in diets with FOR:CON 55:45, and fiber digestibility was not affected. The VFA proportion was slightly influenced by treatment, with butyrate increasing as concentrate increased in the diet. Dry matter and starch digestibility were affected by FOR:CON and were improved in diets with more concentrate. Neutral detergent fiber, $\mathrm{ADF}$, and hemicellulose digestibility were not affected by FOR:CON. Wet and dry feces were reduced linearly as FOR:CON decreased, but total manure was not affected by treatment because of increased urine production with high concentrate diets. In the in situ study, CS showed faster parameters of digestion for DM and NDF than SS. In addition, the fractional rate of digestion was higher for CS. These results suggest that the digestion performance of SS was diminished probably because of the high NDF concentration obtained as a result of late planting. Finally, we determined that rectal grab samples could be an alternative method for estimating starch digestibility in precision-fed dairy heifers because individual time points showed a high correlation with fecal starch obtained by total collection; however, all values were high. Brown mid-rib SS can effectively be fed in precision diets for dairy heifers. Specifically in this study, the FOR:CON 65:35 presented a better performance based on rumen fermentation, VFA, rumen $\mathrm{pH}$, digestibility, and feed efficiency. Further, harvesting the crop at the proper stage of maturity is important for optimizing its nutritional value.

\section{ACKNOWLEDGMENTS}

This research was a component of NC-2042; Management Systems to Improve the Economic and Environmental Sustainability of Dairy Enterprises. Apprecia- tion is extended to Natalie Urrutia of Penn State for support and collaboration, to Danae Oliver of Penn State and Christiane Weinacker of The University of Chile for laboratory assistance and data collection, and to Coleen Jones of Penn State for collaboration and editorial assistance.

\section{REFERENCES}

AOAC International. 2000. Official Methods of Analysis. 17th ed. AOAC International, Gaithersburg, MD.

Aydin, G., R. J. Grant, and J. O'Rear. 1999. Brown midrib sorghum in diets for lactating dairy cows. J. Dairy Sci. 82:2127-2135.

Brown, M. S., C. H. Ponce, and R. Pulikanti. 2006. Adaptation of beef cattle to high-concentrate diets: Performance and ruminal metabolism. J. Anim. Sci. 84:E25-E33.

Calsamiglia, S., P. W. Cardozo, A. Ferret, and A. Bach. 2008. Changes in rumen microbial fermentation are due to a combined effect of type of diet and pH. J. Anim. Sci. 86:702-711.

Colucci, P. E., G. K. MacLeod, W. L. Grovum, L. W. Cahill, and I. McMillan. 1989. Comparative digestion in sheep and cattle fed different forage to concentrate ratios at high and low intakes. J. Dairy Sci. 72:1774-1785.

Corona, L., S. Rodriguez, R. A. Ware, and R. A. Zinn. 2005. Comparative effects of whole, ground, dry-rolled, and steam-flaked corn on digestion and growth performance in feedlot cattle. Prof. Anim. Sci. 21:200-206.

DeVries, T. J., and M. A. G. von Keyserlingk. 2009. Short communication: Feeding method affects the feeding behavior of growing dairy heifers. J. Dairy Sci. 92:1161-1168.

Di Marco, O. N., M. S. Aello, M. Nomdedeu, and S. Van Houtte. 2002. Effect of maize crop maturity on silage chemical composition and digestibility (in vivo, in situ and in vitro). Anim. Feed Sci. Technol. 99:37-43.

Di Marco, O. N., M. A. Ressia, S. Arias, M. S. Aello, and M. Arzadin. 2009. Digestibility of forage silages from grain, sweet and BMR sorghum types: Comparison of in vivo, in situ and in vitro data. Anim. Feed Sci. Technol. 153:161-168.

Emile, J. C., M. Al Rifai, X. Charrier, P. Leroy, and Y. Barriere. 2006. Grain sorghum silages as an alternative to irrigated maize silage. Grassl. Sci. Eur. 11:80-82.

Fredin, S. M., L. F. Ferraretto, M. S. Akins, P. C. Hoffman, and R. D. Shaver. 2014. Fecal starch as an indicator of total-tract starch digestibility by lactating dairy cows. J. Dairy Sci. 97:1862-1871.

Fuentes, M. C., S. Calsamiglia, P. W. Cardozo, and B. Vlaeminck. 2009. Effect of $\mathrm{pH}$ and level of concentrate in the diet on the production of biohydrogenation intermediates in a dual-flow continuous culture. J. Dairy Sci. 92:4456-4466.

Grant, R. J. 1994. Influence of corn and sorghum starch on the in vitro kinetics of forage fiber digestion. J. Dairy Sci. 77:1563-1569.

Grant, R. J., S. G. Haddad, K. J. Moore, and J. F. Pedersen. 1995 Brown midrib sorghum silage for midlactation dairy cows. J. Dairy Sci. 78:1970-1980.

Greter, A. M., B. L. Kitts, and T. J. DeVries. 2011. Short communication: Limit feeding dairy heifers: Effect of feed bunk space and provision of a low-nutritive feedstuff. J. Dairy Sci. 94:3124-3129.

Hall, M. B. 2009. Determination of starch, including maltooligosaccharides, in animal feeds: Comparison of methods and a method recommended for AOAC collaborative study. J. AOAC Int. 92:42-49.

Joshi, N. P., and T. H. Herdt. 2006. Rumen metabolism. Section J. Pages 270-286 in Production Diseases in Farm Animals: 12th Int. Conf.. Wageningen Acad. Publ., Wageningen, the Netherlands. https://doi.org/10.3920/978-90-8686-571-0.

Kenward, M. G., and J. H. Roger. 1997. Small sample inference for fixed effects from restricted maximum likelihood. Biometrics 53:983-997.

Lascano, G. J. 2011. Optimizing nutrient utilization of a precision feeding. Doctoral dissertation, The Pennsylvania State University, State College. 
Lascano, G. J., and A. J. Heinrichs. 2009. Rumen fermentation pattern of dairy heifers fed restricted amounts of low, medium, and high concentrate diets without and with yeast culture. Livest. Sci. 124:48-57.

Lascano, G. J., G. I. Zanton, A. J. Heinrichs, and W. P. Weiss. 2010. Technical note: A noninvasive urine collection device for female cattle: Modification of the urine cup collection method. J. Dairy Sci. 93:2691-2694.

Lascano, G. J., G. I. Zanton, F. X. Suarez-Mena, and A. J. Heinrichs. 2009. Effect of limit feeding high- and low-concentrate diets with Saccharomyces cerevisiae on digestibility and on dairy heifer growth and first-lactation performance. J. Dairy Sci. 92:5100-5110.

Little, O., E. Cheng, and W. Burroughs. 1958. Effects of chelating agents on cellulose digestion in vitro by rumen microorganisms. J. Anim. Sci. 17:1190. (Abstr.)

McCorkle, D. A., D. Hanselka, B. Bean, T. McCollum, S. Amosson, S. Klose, and M. Walle. 2007. The economic benefits of forage sorghum silage as an alternative crop. MKT-3557L. Texas Cooperative Extension, College Station. Accessed Jun. 1, 2016. http:// publications.tamu.edu/FORAGE/PUB_forage_Economic\%20 Benefits $\% 20$ of $\% 20$ Forage.pdf.

Merchen, N. R., J. L. Firkins, and L. L. Berger. 1986. Effect of intake and forage level on ruminal turnover rates, bacterial protein synthesis and duodenal amino acid flows in sheep. J. Anim. Sci. $62: 216-225$.

Mertens, D. R. 2005. Rate and extent of digestion. Pages 13-47 in Quantitative Aspects of Ruminant Digestion and Metabolism. J. Dijkstra, J. M. Forbes, and J. France, ed. CABI, Cambridge, MA.

Mertens, D. R., and J. R. Loften. 1980. The effect of starch on forage fiber digestion kinetics in vitro. J. Dairy Sci. 63:1437-1446.

Miron, J., E. Zuckerman, G. Adin, R. Solomon, E. Shoshani, M. Nikbachat, E. Yosef, A. Zenou, Z. G. Weinberg, Y. Chen, I. Halachmi, and D. Ben-Ghedalia. 2007. Comparison of two forage sorghum varieties with corn and the effect of feeding their silages on eating behavior and lactation performance of dairy cows. Anim. Feed Sci. Technol. 139:23-39.

Moody, M. L., G. I. Zanton, J. M. Daubert, and A. J. Heinrichs. 2007. Nutrient utilization of differing forage-to-concentrate ratios by growing Holstein heifers. J. Dairy Sci. 90:5580-5586.

Moore, K. J., and J. H. Cherney. 1986. Digestion kinetics of sequentially extracted cell wall components of forages. Crop Sci. 26:12301235 .

NRC. 2001. Nutrient Requirements of Dairy Cattle. 7th rev. ed. Natl. Acad. Press, Washington, DC.

Oba, M., and M. S. Allen. 2000. Effects of brown midrib 3 mutation in corn silage on productivity of dairy cows fed two concentrations of dietary neutral detergent fiber: 1 . Feeding behavior and nutrient utilization. J. Dairy Sci. 83:1333-1341.

Oliver, A. L., R. J. Grant, J. F. Pedersen, and J. O'Rear. 2004. Comparison of brown midrib- 6 and -18 forage sorghum with conventional sorghum and corn silage in diets of lactating dairy cows. J. Dairy Sci. 87:637-644.

Owens, F. N., and R. A. Zinn. 2005. Corn grain for cattle: Influence of processing on site and extent of digestion. Pages 86-112 in Proc. Southwest Nutr. Conf. Tucson, AZ. Univ. Arizona, Tucson.

Pino, F., and A. J. Heinrichs. 2016. Effect of trace minerals and starch on digestibility and rumen fermentation in diets for dairy heifers. J. Dairy Sci. 99:2797-2810.

Pino, F. H., and A. J. Heinrichs. 2014. Comparison of on-farm foragedry-matter methods to forced-air oven for determining forage dry matter. Prof. Anim. Sci. 30:33-36.

Ramos, S., M. L. Tejido, M. E. Martinez, M. J. Ranilla, and M. D. Carro. 2009. Microbial protein synthesis, ruminal digestion, microbial populations, and nitrogen balance in sheep fed diets varying in forage-to-concentrate ratio and type of forage. J. Anim. Sci 87:2924-2934.

Sarwar, M., J. L. Firkins, and M. L. Eastridge. 1991. Effect of replacing neutral detergent fiber of forage with soyhulls and corn gluten feed for dairy heifers. J. Dairy Sci. 74:1006-1017.

Schlenker, W., and M. J. Roberts. 2009. Nonlinear temperature effects indicate severe damages to U.S. crop yields under climate change. Proc. Natl. Acad. Sci. USA 106:15594-15598.

Van Soest, P. J. 1994. Nutritional Ecology of the Ruminant. 2nd ed. Cornell Univ. Press, Ithaca, NY.

Van Soest, P. J., J. B. Robertson, and B. A. Lewis. 1991. Methods for dietary fiber, neutral detergent fiber, and nonstarch polysaccharides in relation to animal nutrition. J. Dairy Sci. 74:3583-3597.

Yang, C. M. J., and G. A. Varga. 1989. Effect of three concentrate feeding frequencies on rumen protozoa, rumen digesta kinetics, and milk yield in dairy cows. J. Dairy Sci. 72:950-957.

Zanton, G. I., and A. J. Heinrichs. 2008. Rumen digestion and nutritional efficiency of dairy heifers limit-fed a high forage ration to four levels of dry matter intake. J. Dairy Sci. 91:3579-3588.

Zanton, G. I., and A. J. Heinrichs. 2009. Review: Limit-feeding with altered forage-to-concentrate levels in dairy heifer diets. Prof. Anim. Sci. 25:393-403.

Zanton, G. I., and A. J. Heinrichs. 2016. Efficiency and rumen responses in younger and older Holstein heifers limit-fed diets of differing energy density. J. Dairy Sci. 99:2825-2836.

Zinn, R. A., A. Barreras, L. Corona, F. N. Owens, and R. A. Ware. 2007. Starch digestion by feedlot cattle: Predictions from analysis of feed and fecal starch and nitrogen. J. Anim. Sci. 85:1727-1730. 